\title{
Тувинская литература периода Тувинской Народной Республики: рождение поэтики художественной модальности
}

\author{
Уран А. Донгак \\ Тувинский институт гуманитарных и прикладных социально-экономических исследований \\ при Правительстве Республики Тыва, Российская Федерация
}

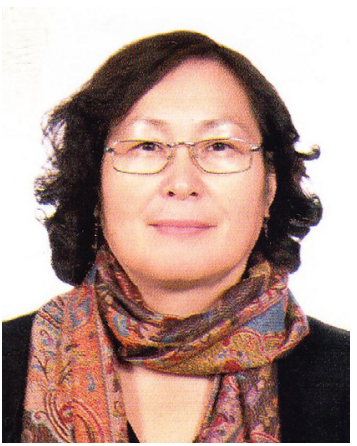

В статье анализируется история зарождения тувинской национальной литературы в период Тувинской Народной Республики (1921-1944 г2.). Новизна работы заключается в обнаружении процесса перехода от традиционализма (фольклорного сознания) к индивидуально-авторскому творчеству в основных категориях исторической поэтики - Жанр, Автор, Стиль. В контексте «большого» исторического времени выделяется поэтика художественной модальности на начальном этапе становления литературного сознания.

В одном из первых литературных изданий тувинской литературы «Сььndь cogaaldar» («Избранные произведения») 1939 г. выделяются тексты разного структурного характера: произведения в канонической форме народной песни, коллективно сочиненные новые песни революционного содержания (аратские песни) и произведения собственно авторские, а также лозунговые стихотворения-призывы. Показано, ито тувинская литература в 1930-е г2. еще использует традиционалистскую поэтику, но поэтика художественной модальности уже актуализируется.

Ключевые слова: Тува; Тувинская Народная Республика; история Тувы; тувинская литература; тувинский язык; тувинская поэзия; историческая поэтика; традиционалистская поэтика; поэтика художественной модальности; аратская песня; лозунговое стихотворение; шүлүк

\section{Для цитирования:}

Донгак У. А. Тувинская литература периода Тувинской Народной Республики: рождение поэтики художественной модальности // Новые исследования Тувы. 2020, № 3. С. 151-165. DOI: www.doi.org/10.25178/nit.2020.3.11

Донгак Уран Алдын-ооловна - кандидат филологических наук, ведущий научный сотрудник группы литературоведения Тувинского института гуманитарных и прикладных социально-экономических исследований при Правительстве Республики Тыва. Адрес: 667000, Россия, г. Кызыл, ул. Кочетова, д. 4. Тел.: +7 (394-22) 3-39-36, +7 (913) 348-16-12. Эл. адрес: uranda@yandex.ru

DONGAK, Uran Aldyn-oolovna, Candidate of Philology, Leading Researcher, Group of literary criticism, Tuvan Institute of Humanities and Applied Social and Economic Research under the Government of the Republic of Tuva. Postal address: 4 Kochetov St., 667000 Kyzyl, Russian Federation. Tel.: +7 (394-22) 3-39-36, +7 (913) 348-16-12. E-mail: uranda@yandex.ru 


\title{
Tuvan literature under the Tuvan People's Republic: The birth of the poetics of artistic modality
}

\author{
Uran A. Dongak \\ Tuvan Institute of Humanities and Applied Social and Economic Research \\ under the Government of the Republic of Tuva, Russian Federation
}

\begin{abstract}
The article analyses the history of the origin of Tuvan national literature during the period of the Tuvan People's Republic (1921-1944). We have traced the process of transition from traditionalism (folklore consciousness) to individual author's creativity in the main categories of historical poetics, which are that of genre, author and style. The article also identifies the poetics of artistic modality as the initial stage of the literary consciousness in the context of historical time.

One of the first Tuvan literary publications "Cbbndb cogaaldar" ("Selected works") contains diversely constructed texts, such as pieces of folk songs in canonical form, collective songs of revolutionary content (arats' songs) and works which had specific individual authors, as well as slogan poems. Tuvan literature of the 1930s still uses traditional poetics, but the poetics of artistic modality is already being actualized.
\end{abstract}

Keywords: Tuva; Tuvan People's Republic; Tuvan history; Tuvan literature; Tuvan language; Tuvan poetry; historical poetics; traditional poetics; poetics of artistic modality; arats' song; slogan poem; shuluk

\section{For citation:}

Dongak U. A. Tuvinskaia literatura perioda Tuvinskoi Narodnoi Respubliki: rozhdenie poetiki khudozhestvennoi modal'nosti [Tuvan literature under the Tuvan People's Republic: The birth of the poetics of artistic modality]. New Research of Tuva, 2020, no. 3, pp. 151-165. (In Russ.). DOI: www.doi.org/10.25178/nit.2020.3.11

\section{Введение}

Рождение феномена литературного творчества в 1920-1940-е годы в Туве - одно из ярчайших свидетельств эпохальных изменений, произошедших в тувинском обществе в годы Тувинской Народной Республики (далее - ТНР). Проблема нашего исследования - процесс зарождения тувинской национальной литературы в период ТНР (1921-1944 гг.).

Актуальность исследования тувинской литературы на начальном этапе ее становления с позиций исторической поэтики, согласно которой в начале XX века в литературах Востока выделяется переходный период от традиционалистской (эйдетической) $)^{1}$ эпохи к новой эпохе художественной модальности (индивидуально-творческой), заключается в анализе поэтики тувинской литературы, в изучении эволюции ее поэтических средств, в определении места тувинской литературы в контексте литературного развития.

Цель статьи - на примере одного из первых литературных изданий тувинской литературы «Сььndь cogaaldar» («Чыынды чогаалдар» - «Избранные произведения») 1939 г., объединившего стихотворные произведения первых тувинских писателей (Научный архив Тувинского института гуманитар-

\footnotetext{
${ }^{1}$ В исторической поэтике в настоящее время не выработана единая терминология относительно названий литературных эпох. Исследователи предлагают ряд названий литературных эпох и соответственно их поэтик, согласно того понимания, какое вкладывает каждый ученый в их дефиницию: 1) поэтика синкретизма (А. Н. Веселовский, С. С. Бройтман и др.), эстетика тождества (Ю. М. Лотман), фольклор, архаическая, мифопоэтическая, дорефлексивного традиционализма; 2) также эстетика тождества (Ю. М. Лотман), поэтика синкретизма (А. Н. Веселовский), поэтика рефлексивного традиционализма, традиционалистская, нормативная, риторическая, эйдетическая (С. С. Бройтман), эпоха поэзии; 3) эстетика противопоставления (Ю. М. Лотман), поэтика личного творчества (А. Н. Веселовский), рефлексивная поэтика, индивидуально-творческая, неканоническая, нетрадиционалистская, эпоха прозы, поэтика автора (С. С. Аверинцев и др.), поэтика художественной модальности (С. С. Бройтман и др.) (Тамарченко, Тюпа, Бройтман, 2004: 12-13).
} 
ных и прикладных социально-экономических исследований при Правительстве Республики Тыва далее НА ТИГПИ, кф2457, 158a), показать условия зарождения тувинской литературы в период ТНР, отражающие процесс перехода тувинской художественной культуры от традиционалистской поэтики - к новой, в силу основных ее характеристик определяемой некоторыми исследователями как индивидуально-творческая или поэтика художественной модальности.

В достижении поставленной цели актуально решение следующих задач: показать, какими характеристиками обладали первые художественные произведения на тувинском языке и чем они качественно отличались от фольклорных произведений; проследить процесс перехода от традиционализма (фольклорного сознания) к индивидуально-авторскому творчеству в основных категориях исторической поэтики: Жанр, Автор, Стиль.

Теоретико-методологической базой в изучении данного вопроса являются исследования по истории русской литературы XX века Л. П. Кременцова, С. И. Кормилова, М. О. Чудаковой и др. (Кременцов, 2016; История русской ..., 1998; Чудакова, 2002), по художественным особенностям метода социалистического реализма в русской и советской многонациональной литературе Е. А. Добренко,М. А. Литовская и др. (Добренко, 2007; Литовская, 2008), а также исследования по истории тувинской литературы Д. С. Куулара, А. К. Калзана, З. Б. Самдан и других (Куулар, 1970; Калзан, 1958; Самдан, 1987) и труды известных отечественных литературоведов С. С. Аверинцева, М. М. Бахтина, С. Н. Бройтмана и других по исторической поэтике (Аверинцев и др., 1994; Бахтин, 1986; Бройтман, 2004).

В тувиноведении начальный период тувинской литературы изучался А. К. Калзаном - вопросы драматургии (Калзан, 1958), Д. С. Кууларом - становление поэзии (Куулар, 1970). Выходили коллективные монографии по истории тувинской литературы 1975 г. и 2013 г. (Тыва ..., 1975; История ..., 2013). Исследователи собрали богатые фактографические данные и анализировали поэтику первых литературных произведений тувинских авторов (НА ТИГПИ, рф, д. 327, л. 40-59).

Несмотря на имеющиеся исследования, в тувинском литературоведении не решалась проблема становления тувинской литературы с позиций исторической поэтики, в частности смены традиционалисткой поэтики на поэтику художественной модальности. Это определяет новизну данного исследования. Мы выделим в контексте «большого» исторического времени поэтику художественной модальности на начальном этапе становления литературного сознания в тувинской культуре. Не различение фольклорного и литературного художественного сознания при анализе литературы в период ее зарождения и становления приводило многих исследователей к весьма размытым выводам о характеристиках, слабо различающим поэтику произведений начального периода и, следовательно, личный авторский почин первых тувинских литераторов в создании художественных произведений.

Источниковой базой исследования выступили произведения тувинских авторов указанного периода: С. А. Сарыг-оола, С. Б. Пюрбю, А. Ч. Тамба-Сюрюна, М. Ы. Идам-Сюрюна, С. К. Самба-Люндупа и др.

\section{Изучение особенностей поэтики тувинской литературы 1930-х 22.}

Изучение условий создания тувинской национальной литературы, как результата длительного процесса эволюции изобразительно-выразительных средств, как части культуры, духовной жизни народа, является важным в определении поэтических средств, какие были задействованы в создании художественных произведений данного периода.

Особенности поэтики художественных произведений 1930-х гг. выделяют исследователи истории тувинской литературы: Д. С. Куулар, А. К. Калзан, З. Б. Самдан, Л. С. Мижит.

Так, при анализе первых произведений тувинских авторов Д. С. Куулар обращает внимание на такие, на наш взгляд, разноструктурные характеристики художественного творчества, как: с одной стороны, простое перечисление, каноны народной песни, повествование в замедленном сказочном ритме, ораторские приемы; с другой - публицистичность, выразительность языка, двустрочные строфы в форме призыва-лозунга, нарушение песенного стихотворного размера, декламационная интонация, новые ритмы, метафоризация, нотки чистой лирики, новые жанры и другие (Куулар, 1970: 19-44).

А. К. Калзан, обращаясь к вопросу о роли тувинской художественной литературы в формировании и развитии национального литературного языка, отмечает, что в 1920-1930-е гг. рождение новых литературных жанров происходило под сильным влиянием фольклора, писатели «непосредственно копировали формы» устного народного творчества, и, первую очередь, это касалось, конечно, поэтики народных песен (НА ТИГПИ, рф., д. 2106, л. 3). 
В монографическом исследовании 3. Б. Самдан «От фольклора к литературе: на материале тувинской прозы 40-70-х годов» (Самдан, 1987) для нас важно понимание двух моментов в изучении истории тувинской литературы: 1) понимание изменения поэтики художественной литературы как эволюционного процесса; 2) возможность сосуществования фольклорного и литературного типов сознания в переходную эпоху (там же: 4-5).

О сильном фольклорном влиянии, риторике и нововведениях в поэтике первых стихотворных произведений тувинских поэтов также пишет Л. С. Мижит (Мижит, 2013: 152-171). Выделяя фольклорное начало как доминирующее в поэзии анализируемого периода, исследователи, тем не менее, констатируют факт зарождения новых поэтических жанров в тувинской поэзии: поэзия для детей, сатирические стихи, стихи-отклики, баллада, поэма, лирические стихи (Куулар, 1970: 35, 37; Мижит, 2013 : $162,184)$.

Литературные тексты тувинских авторов названного исторического периода с позиций исторической поэтики еще не были предметом исследования. Данный подход, предполагающий изучение эволюции художественно-изобразительных средств в контексте смены литературных эпох, был использован нами ранее при анализе произведений архаической поэтики (мифопоэтической); современного периода истории тувинской литературы: советского и постсоветского, а также переходного периода от фольклора к литературе. В частности, характеризуя поэтику переходного периода, сообщается о феномене коллективного авторства, как проявления архаического и традиционалистского художественного сознания; о регламентированности тувинской поэзии на начальном этапе ее становления; ее жанровой приуроченности, а также о том, что в переходный период от фольклора к литературе категория авторства уверенно закрепляется в художественном сознании эпохи, а жанровые разграничения неопределенны и изменяемы (от беллетризованных воспоминаний и автобиографических рассказов к новеллам, повести и роману) (Донгак, 2012ab, 2010). Эти публикации требуют развития в разработке данной проблематики, уточнения некоторых формулировок и конкретного анализа текстов с целью выявления собственно литературной парадигмы этого культурного феномена.

\section{Зарождение тувинской литературы}

История тувинской литературы начинается с 1920-х гг., и начало это непосредственно связано с таким судьбоносным историческим событием в жизни народа, как создание в 1921 г. в Центре Азии государства - Тувинской Народной Республики. Одним из первых шагов культурного развития в годы ТНР явился выпуск газет и журналов на русском (газета «Красный пахарь», 1924 г.), старомонгольском письменном (с 1925 г.) и тувинском языках (газета «Шын», 1930 г.) (Танова, 1979; Маадыр, Седип-оол, 2020). Создание национальной письменности в 1930 г. было непосредственно связано, в свою очередь, с массовым сочинительством, коллективным творчеством в разных видах литературы, активной переводческой деятельностью; изданием газет, журналов, книг (Маадыр, 2011).

В 1926-1927 гг. были напечатаны первые авторские сочинения тувинцев. Они были созданы на монгольском языке тувинской молодежью, владеющей монгольской грамотой и входившей в члены Тувинской Народно-Революционной Партии (ТНРП) и Тувинского Революционного Союза молодежи (Тувревсомол). В периодических изданиях партийно-правительственных органов, печатавшихся на старомонгольском письменном языке, были опубликованы первые стихотворения тех лет. Истории тувинской литературы известны два имени авторов первых оригинальных сочинений тувинской литературы, опубликованных на старописьменном монгольском языке в 1927-1929 гг. Это: партийный работник - генеральный секретарь ЦК ТНРП Монгуш Содунам, владевший старомонгольским письмом, и активистка женского движения Донгак Барыкаан, научившаяся монгольской грамоте в семейном кругу (Куулар, 1970: 15-17; Кенин-Лопсан, 1995; Донгак, 2012с).

Создание тувинской национальной письменности стало также той отправной точкой, когда владеющая грамотой тувинская молодежь получает возможность художественно выражать свои мысли и чувства, рожденные небывалыми изменениями в тувинском обществе, на родном языке. Газеты «Şьn» («Шын» - «Правда), «Хostuq arat» («Хостуг арат» - «Свободный арат»), «Areve şьnь» («Аревэ шыны» «Ревсомольская правда») начинают публиковать их сочинения. Это были произведения, как отмеченные авторством, так и без указания авторства. «Начинающие тувинские авторы увлеченно пишут стихи, очерки, фельетоны, рассказы, пьесы. Тридцатые годы в Туве отчасти примечательны тем, что тогда наблюдалось массовое увлечение молодежи литературой. Каждому хотелось выразить свои чувства, 
рожденные революционным духом времени, в поэтических строках. Вместе с тем новизна письменной литературы вызвала у тувинской молодежи большой интерес, даже газетные корреспонденции подчас завершались стихотворными призывами», - пишет первый историк тувинской литературы А. К. Калзан (НА ТИГПИ, рф., д. 327, лл. 34-35).

Массовое творчество тувинцев выражалось в таких художественных формах, как: 1) авторские произведения, подписанные именем сочинителя, 2) произведения без указания авторства, 3) а также рожденный в эти годы феномен коллективного, точнее корпоративного авторства, отличный от безымянного фольклорного. Из числа активистов-ревсомольцев, государственных служащих, работников газет и журналов, сельских активистов-корреспондентов, первых учителей, получивших первоначальное обучение в семьяхили буддийскихмонастырях-хурээу монгольскихлам, в немногочисленных русских школах и первых светских школах для тувинцев с обучением на монгольском языке; в летних школах по обучению сначала монгольской и русской грамоте, а с 1930 г. - тувинской грамоте, в передвижных «красных» юртах (кызыл өг), начавших работать с 1923 г., постепенно выделились талантливые литераторы: С. Пюрбю, С. Тока, С. Сарыг-оол, Б. Ховенмей, О. Саган-оол, В. Кок-оол, А. ТамбаСюрюн и другие.

Тувинское правительство, вводя вышеозначенные формы, стало отправлять молодежь на учебу в Монголию (г. Улан-Батор), СССР (г. Москва, КУТВ - С. Тока, С. Сарыг-оол, Б. Ховенмей, В. Кок-оол, С. Самба-Люндуп; г. Ленинград, Курсы нацменьшинств Советского Востока при Ленинградском Восточном институте им. Еникудзе - С. Пюрбю; г. Ойрот-Тура (г. Горный Алтай) - О. Сегленмей; Улан-Удэ, рабфак - О. Саган-оол и др.). Оттуда возвращались специалисты сельского хозяйства, финансового дела, партийные работники, учителя, почти все они пробовали себя как корреспонденты, сочинители песен, стихотворений, фельетонов, но лишь единицы впоследствии стали знаменитыми писателями, авторами любимых народом произведений.

В 1930-е годы в ТНР публикуются сначала в периодической печати, а позже отдельными книжками первые авторские произведения на тувинском языке. В тувинской поэзии, как пишет Д. С. Куулар, заявили о себе первые талантливые поэты: С. Сарыг-оол, С. Пюрбю, Б. Ховенмей (Куулар, 1970: 23). «Свобода» С. Сарыг-оола, «Солнце, взошедшее с запада» С. Пюрбю, «Знамя Октября» Б. Ховенмея - эти стихи вышли в печать в 1934 г. и они, как отмечает Д. С. Куулар, «отвечали основным требованиям современной поэзии», «теперь в них начинает превалировать образное воспевание действительности» (там же). Они создаются по законам поэтического слова, все меньше в них рифмованных призывов, все больше художественного изображения действительности, ее образного воспевания. Поэты 1930-х гг., овладевая искусством создания стихотворных произведений, постепенно расширяют тематический кругозор, в поэзии выделяются разные жанровые образования: Д. С. Куулар отмечает, что в эти годы возникают поэзия для детей, сатирическое в поэзии, первый опыт лиро-эпического жанра - поэма «Чечек» С. Б. Пюрбю, созданная в 1938-1939 гг. (там же: 23, 36-43). Вслед за поэтическими антологиями выходят в свет первые авторские книги С. Пюрбю - баллада «Кызыл коъш» («Красный обоз», 1943) и поэтический сборник «Эртенгиниң ыры» («Песня утра», 1944).

\section{Издания «Сььndь cogaaldar» 1937 и 1939 г2. - первые антологии тувинских авторов}

Два сборника произведений «Сььndь cogaaldar» («Чыынды чогаалдар»-«Избранные произведения») 1937-го и 1939-го гг. (фото 1 и 2) с одинаковым названием вышли в свет на тувинском языке с использованием тувинской письменности на основе латиницы (яналиф), тиражом соответственно 4000 и 3000 экземпляров. Несколько экземпляров этих двух изданий, выпущенных Государственным книжным издательством ТНР, сегодня также хранятся в научном архиве ТИГПИ и отделе редкой книги Национальной библиотеки им. А. С. Пушкина Республики Тыва. В них напечатаны первые произведения тувинских авторов и произведения устного народного творчества. В предисловии сборника 1939 г., как и в первой книге 1937 г., посвященной 6-му хуралу (съезду) Ревсомола сообщается, что здесь собраны лучшие образцы литературных произведений того времениํ․

\footnotetext{
${ }^{1}$ Название этих изданий, учитывая факт первого опыта антологии художественных произведений на тувинском языке, в предыдущих статьях нами переводилось не как «Избранные произведения», а ошибочно - как «Собрание произведений».
} 

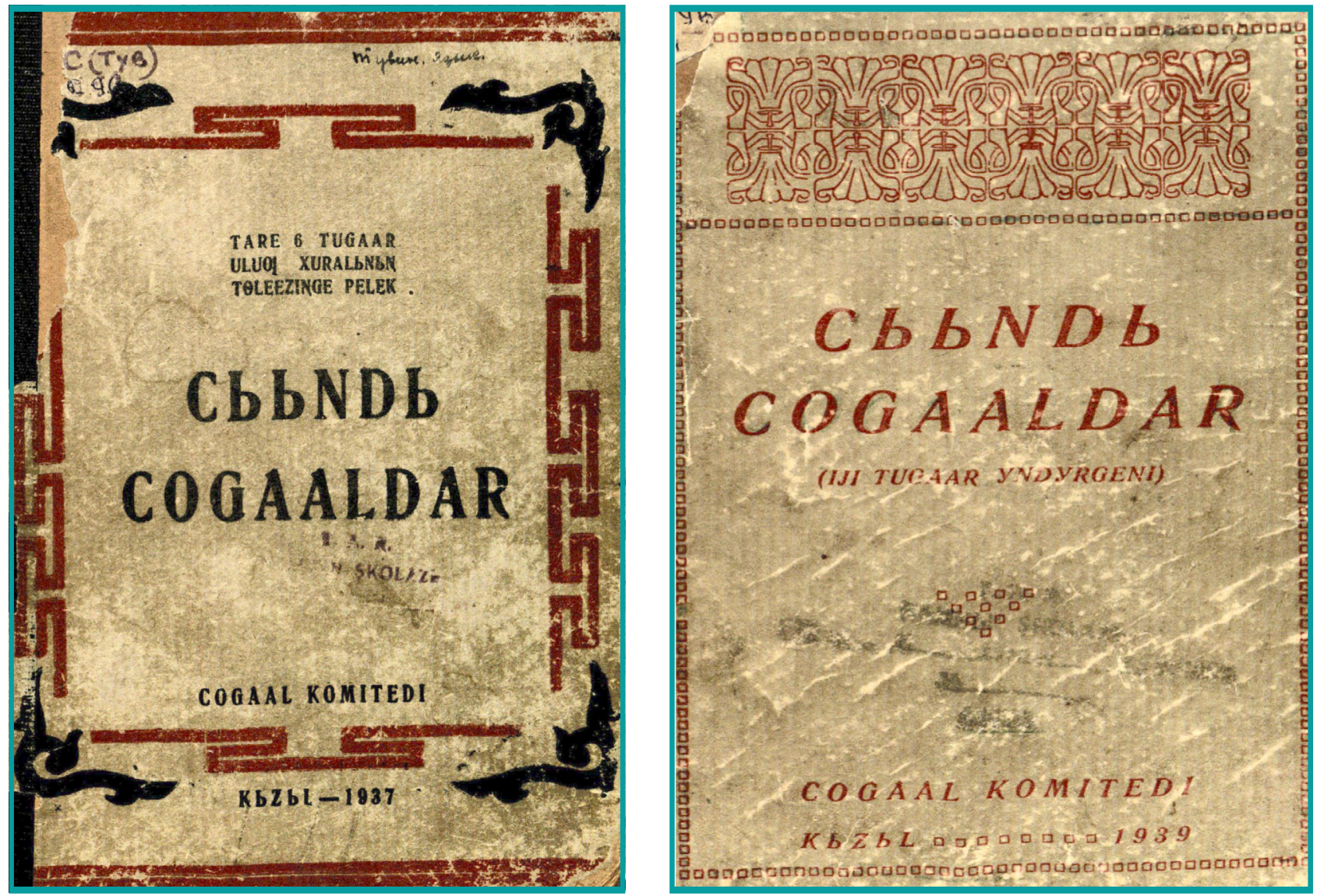

Фото 1 и 2. Обложки сборников «Сьbnd с cogaaldar» 1937 и 193922.

Photos 1 and 2. Covers of the "Cobnd cogaaldar" collections, 1937 and 1939.

О составителях этих двух сборников нам практически ничего не известно, есть лишь записи, помещенные на титульном листе: в сборнике 1937 г. составитель и ответственный редактор - Очурбаанак, в сборнике 1939 г. - Ойдуп.

Д. С. Куулар оценивает издание этих книг как факт приобретения молодой тувинской поэзией профессионального характера (Куулар, 1970: 45). В 1-м томе «Истории тувинской литературы» 2013 г. автор раздела о тувинской поэзии в период ТНР Л. С. Мижит несколько подробнее останавливается на этом литературном факте (Мижит, 2013: 152-154). Она представила авторский состав поэтического сборника «Сььndь cogaaldar» 1937 г., отметив, ссылаясь на А. К. Калзана, что молодые «стихотворцы, стремясь создать стиль письменной поэзии, вносили в народный язык свежую струю» (там же: 154) ${ }^{1}$ Оба поэтических сборника 1937 и 1939 гг. открываются международным пролетарским гимном «Интернационал» на тувинском языке без указания переводчика. В книге 1939 г. далее опубликована аратская песня «Кайгамчыктыг Интернационал» («Дивный Интернационал»)2. Эти два произведения начинают первую часть сборника, обозначенную как «Ырлар» («Песни»).

${ }^{1} \mathrm{~K}$ сожалению, автор недостаточно точно передает некоторые факты. Во-первых, в сборнике 1937 г. были изданы все выходившие в периодической печати стихи и песни. Однако вспомним упоминание составителей книги о том, что в данном сборнике печатаются лучшие образцы стихотворных произведений этих лет. Вместе с тем в предисловии сборника 1939 г. сообщается, что в книгах, журналах, на страницах газет сотнями печатаются песни, стихи первых сочинителей (НА ТИГПИ, кф2457, л. 7). Во-вторых, песня «Интернационал» представлена как результат коллективного сочинения. Для нас же относительно песни «Интернационал» важно то, что это был тувинский перевод международного пролетарского гимна Э. Потье, осуществленный с русского текста А. Коца. Таким образом, в данном литературном факте мы отмечаем начало приобщения тувинских литераторов к мировой сокровищнице поэтического творчества через посредство русского языка. В-третьих, в сборник 1939 г., как пишет Л. С. Мижит, вошли загадки и сказки (Мижит, 2013: 152-154), а верно: пословицы и одно сказание. Уточнения по перечисленным фактам важны для характеристики начального периода становления тувинской литературы: для установления массового характера сочинительства аратских песен.

2 Здесь и далее цитаты из произведений и их названия приводятся кириллицей без латинского письма (яналифа). 
Всего в эти два сборника включены произведения более чем восьмидесяти авторов, что, безусловно, указывает на массовый характер сочинительства в эти годы. Самыми известными, впоследствии ставшими именитыми писателями Тувы, авторами названных двух сборников, являются: Сарыг-оол (Sarьq-ool), Ховенмей (Хөвепmеј), Пюрбю (Ругву), Тока (Toka), Кок-оол (Kөk-ool), Тамбы-сюрюн (Татвьsyryn), Кара-кыс (Kara-kьs), Самба-люндуп (Samba-lyndyp), М. Идам-сюрюн (M. Idam-syryn). Как видно, в подавляющем большинстве авторами первых сочинений на родном языке стала молодежь. Многие из них впоследствии стали известными партийными, государственными деятелями, или писателями, журналистами, артистами тувинского театра, например, народные писатели С. А. Сарыгоол, С. Б. Пюрбю; народная артистка Тувы, заслуженная артистка РСФСР К. Н. Мунзук; заместитель Председателя Совета Министров Тувинской АССР Х. А. Анчымаа-Тока и др.

В обоих изданиях опубликовано более ста стихотворных текстов, более десятка собственно народных песен, несколько стихотворных переводов с русского на тувинский (произведений А. С. Пушкина, «Песни о Родине» («Төрээн чуртум») В. И. Лебедева-Кумача, безымянной песни «Амы-тының бергенне сен» («Жизнь свою отдала [за правое дело]», в переводе с русского Лопсана); одно прозаическое произведение С. Сарыг-оола «Агар-сандан ыяш» («Чудесное дерево»), обозначенное как чаа тоолчугаш - «новая сказка», сказание-тоол «Даш-Хүрең аъттыг Танаа-Херел» («Танаа-Херел с конем ДашХурен») и пословицы.

Содержание книги «Сььndь cogaaldar» 1939 г., как отмечено на титульном листе как «Ийи дугаар үндүргени» («Второе издание, [продолженное]»), почти полностью отличается от первого сборника. Если в первой антологии части книги разделены на тематические блоки: «Произведения о свободе и равенстве», «Произведения, воспевающие родные места», «Стихотворные переводы, посвященные

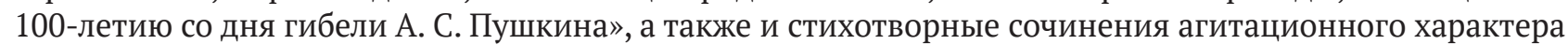
«Произведения о скотоводстве и земледелии», «Произведения о науке и культуре» и т. д., то вторая антология 1939 г. структурирована по следующим разделам: «Песни» (29 текстов), «Пословицы» (64 образца), «Стихотворения» (19 произведений), «Тоол» («Сказание»)․

\section{Рождение поэтики художественной модальности}

Начало XX в. в Туве характеризуется большими социальными и политическими изменениями, интенсивными идеологическими сдвигами, культурным переломом, и все это требовало от субъектов художественного процесса новых форм самовыражения. Процесс создания национальной литературы, возникшей из потребностей самого общества, подготовленной развитием тувинского языка и состоянием устного поэтического творчества народа (Куулар, 1970: 22; НА ТИГПИ, рф., д. 2106, лл. 3-4) был обусловлен тем, что традиционалистская эпоха художественного развития закономерно стала сменяться новой эпохой, определяемой исследователями как индивидуально-творческая (поэтика художественной модальности) (Тамарченко, Тюпа, Бройтман, 2004: 13; Аверинцев и др., 1994: 3).

Основным содержанием индивидуально-творческой эпохи является концепция не готового, создающегося в настоящий момент мира; концепция человека как личности, причем уникальность, неповторимость ее, «единственная единственность» (по М. М. Бахтину) непосредственно связана с миссией создавать мир и создавать себя как личность и неповторимое «я» (цит. по: Тамарченко, Тюпа, Бройтман, 2004: 222). Такое миропонимание, как художественное сознание новой эпохи, закономерно реализуется в принципах поэтического творчества, ее эстетике. Характеризуемая таким образом новая эпоха и соответственно ее поэтика получают название «поэтика художественной модальности» в силу уточнения следующих важных характеристик: переориентация литературного творчества с общественно-публицистической проблематики на индивидуальные пласты сознания, внутреннюю интенцию. В отличие от предыдущей эпохи, где созданный божественным актом мир выступает как канон, образец, а автор - лишь посредник, передатчик слова, в новой поэтике актуализируются подвижное, модальное взаимоотношение «я» и «другого», а также автор как автономный творец, соучаствующий в создании мира. Модальность, понимаемая как изменчивость, принципиальная бесконечность и неопределенность, содержащая «внутреннюю меру» и безграничные возможности в открытии мира и открытие своего «я», является важнейшей характеристикой новой поэтики. Если у человека традиционалистского мира многое было подчинено известному миропорядку, канону,

${ }^{1}$ Тоол в данном случае переводится не как «сказка», а как «сказание». Здесь видно, что терминология еще неточная. 
правилам, то новая личность эпохи художественной модальности активна, она меняет мир и, что не менее важно, меняет себя. Как пишут исследователи: «... на понимание личности был распространен принцип дополнительности, и она предстала как изменяющаяся внутренняя мера “я” и “другого”, как подвижное, модальное, двухполюсное их взаимоотношение» (там же: 222-223).

Книга «Сььndь cogaaldar» 1939 г. стала отражением момента кипения и рождения эстетических принципов новой поэтики в то время, когда традиционалистская поэтика еще не сдавала своих позиций. В анализируемом сборнике мы обнаруживаем художественные тексты разной художественной структуры. Уже содержание, включающее названия «Песни», «Пословицы», «Стихотворения», «Сказание», показывает эту слитность фольклора и собственно литературного творчества в одной книге, призванной представить лучшие произведения нового времени. Внутри одного раздела, кроме частей с народными пословичными выражениями и текстом героического сказания, произведения различаются по форме выражения, идейно-содержательному плану.

Первую группу произведений, вошедших в части «Песни», мы обозначаем как канонические, традиционалистские. Жанровая форма народной песни проявляется здесь по-разному. В поэтическом произведении это, в первую очередь, собственно народные песни, обозначаемые составителями сборника как араттың ыры - «аратская песня». Историками тувинской литературы эти песни называются еще как «новые песни», что следовало из самого названия новых песен революционного содержания. Как пишет А. К. Калзан, они были самым распространенным видом послереволюционного фольклора (Калзан, 1961: 253-254).

Анализируемый сборник содержит аратские песни «Kajgamcьktьø Internasional» («Дивный Интернационал»), «Төge paаrь» («Дөге баары» - «На передней части горы Доге»), «Төр-le surguul turguzarda» («Центральная школа») «Saluuccuttar» («Молодежь»), «Occalandan kedilerin» («Избавление от гнета»). Вместе с тем в этом ряду мы отмечаем одну народную песню, выражающую социальный протест «Ала караан дешкен болза» («Выколоть бы оба глаза»), вскоре всего более раннего периода. Здесь же выделяются собственно народные лирические песни, воспевающие родные места «Кадарчы ыры» («Песня пастуха»), «Таңдым турда таңдаш-ла мен» («Я горд и непреклонен, когда [рядом] моя тайга»), «Межегей», «Самагалдай», «Хандагайты». Все вышеназванные песни обозначены составителями книги как «аратские песни», как видно, понимаемые как «народные песни».

Кроме аратских песен, раздел «Песни» содержит песни авторские, также различаемые в жанровом отношении. Все эти песенные тексты, отмеченные авторством, структурируемы в трех разных формах. В первую очередь, здесь выделяются тексты в канонической форме народной песни. Ее формальными и содержательными признаками являются:

1) тема родины, воспевание родных мест и народных предводителей, многочисленных родственников и ровесников (например, «Шеми бажы сериин чайлаг» Тамбы-сюрюна («В верховьях Шеми прохлада летников»), «Хостуг шөлээн Тыва чуртум» («Свободная родная моя Тува») Делгер-оола, «Ынак өөрүм» («Дорогие мои друзья-ровесники») Мижит-оола);

2) четырехстишная строфа строфической или парной рифмовки. Например:

Тараа малдың сууру болган

Таанда ынак төрээн чуртум,

Тайылбырлап өөреткен

Таанда ынак Тока дарга.
Стала местом хлебородных полей и пастбищ Любимая всеми моя родная сторона, Разъясняющий, обучающий Любимый всеми мой Тока дарга ${ }^{1}$.

(Здесь и далее подстрочный перевод наш. - У. Д.)

3) образный параллелизм;

4) повторы в конце строки и др.

В этой группе произведений совершенно наглядно, что Жанр традиционалистской поэтики активен, авторские тексты заключены в канон народной песни. Стиль традиционалистской поэтики выдержан повторами, параллелизмом, кумуляцией ${ }^{2}$ образов. Интересно, что образ-идея (эйдос) покровителя-предводителя рода наполнен здесь новым содержанием: Тока дарга, Сталин и т. д.; эйдос родной земли - начиная с социально востребованного, например, «Депшилгелиг Тыва чур-

${ }^{1}$ Дарга - начальник.

${ }^{2}$ Кумуляция - в фольклористике: прием, участвующий в построении цепевидных структур, нанизывание. 
ту» («Развивающаяся страна Тува») расширяется понятие «родина» до выражений «Солун чаагай Совет чурту» (Разносторонняя прекрасная страна Советов), «Ачылыг-ла ССРЭ-де» («Милостивый покровительствующий СССР»).

«Песни» включают также авторские сочинения другого плана. В канонической форме народной песни они несут новое содержание. Именно содержательный план позволяет отделить их от предыдущих песен. Здесь мы обозначаем их как новые песни революциионого содержания.

Это: «Эвилелдиг революста» («Благодаря сплачивающей революции») К. Санчай-оола, «Уран мерген чолаачылар» («Умелые мудрые водители») Шактара, «Ал-ла бодум чоргаар-ла мен» («Тогда я горд и независим»), «Баар оруу кегээрелдиг» («Путь их озарен просвещением») Борбак-оола, «Ачылыг-ла нам-на чазак» («Милостивое наше правительство большевиков») Дажы-самбуу. Не чужд этим песням также образный параллелизм, повторы, ритмика народных песен - именно они составляют остов песенной структуры этих произведений. Здесь эйдос, как слитность образно-понятийных начал, выказывает признаки разделения, раскола: система образов машин, водителей, школы и т. д. начинает создавать эстетику новой жизни.

В третьей группе произведений, вошедших в часть «Песни», мы выделяем произведения собственно авторские: в них Жанр, как канон народной формы, ослабляется новым содержанием, образы более независимы от понятийного начала и самостоятельны.

Это произведения: «Аныяктар» («Молодежь») и «Уран чогаал» («Литература») Кара-кыс, «Эрге шөлээ бисте турда» («Когда свобода и воля в наших руках») Т. А. Сарыг-оола, «Пионер чараш» («Как прекрасен пионер») Биче-уруг, «Уран чечен аныяктар» («Талантливая молодежь») Тамбы-сюрюна.

В названных выше песнях индивидуально-творческое, авторское начало проявляется зримее, несмотря на жанровую форму народной песни и новое революционное содержание. Авторство как выражение личной сопричастности миру («Оран чурттуң ажыл херээн // Онза кылдыр хөгжүдээли»«Дела, хозяйство родной земли // Давайте по-особому развивать» Тамбы-сюрюн), активной деятельности («Аныяктар белен-не бис, чорудаалы, узуткаалы» - «Мы, молодые, готовы, давайте проведем, давайте истребим»), творческого переосмысления традиционного.

Культурный перелом начинает проявляться в этих произведениях все отчетливее. Образ, отделяясь от идеи, обретает собственную содержательность, например, в произведениях «Молодежь», «Как прекрасен пионер», а также в следующем примере:

Сайзыралды харап көөрге,

Саян даг дег бедик болган,

Саазынга чуруп көөрге,

Сайгылгаан дег чырык болган

(Т. А. Сарыг-оол)
Когда всматривались издалека в сторону развивающихся (стран), Они казались такими (недосягаемыми) высокими, словно Саяны, Когда изобразили на листе бумаги,

Оказалось таким светлым, словно свет электрических лампочек.

Концепция созидания нового мира активна в поэтике этих произведений.

Третья часть книги «Сььndь cogaaldar» 1939 г., озаглавленная как «Шүлүктер» («Стихотворения»), в первую очередь, указывает на то, что вошедшие сюда художественные тексты во многом отличны от песенных произведений.

Неканоническая новая жанровая форма шүлүк - «стихотворение» - свидетельствует о рождении нового поэтического жанра. В отличие от традиционалистской поэтики в ней Жанр теряет свою самостоятельность, подавляющую самость, через него проявляются Стиль и категория Автор.

В новой поэтике, где важнейшим и довлеющим над всем остальным является категория авторства, мы отмечаем в сборниках 1937-го и 1939 гг. авторские произведения и произведения коллективного авторства, обозначенные или не обозначенные должным образом. В разделе «Стихотворения» все произведения авторские. Тем не менее, некоторые тексты все же отмечены тягой к традиционалистской поэтике, имеют черты народного творчества.

Риторическое слово как поэтика готового слова, оперирующая готовым репертуаром смыслов, является основным изобразительным средством лозунговых стихотворений - призывов. Они призваны, главным образом, при помощи воспроизведенного готового слова сообщить в художественной форме о достижениях настоящего и горестях прошлого; призывами к действиям - упорядочить изображаемую действительность, гармонизировать воображаемый мир. Такова одна из главных особенностей эстетики соцреалистического искусства (Донгак, 2013: 123). 
Поэтика традиционалистская, с одной стороны, и соцреалистическая - с другой, наиболее ярко отражена в структуре первых стихотворных произведений тувинских авторов сборника 1939 г. Это произведения Хойлакаа «Башкы Ленин мөчүзе-даa, // Баъштап берген херээ дириг» - «Учитель Ленин умер, // Но дело его живо», С. Байыра «Чаа чурт делгерезин» - «Да здравствует новая страна», М. Идамсюрюна «Херээжен деп атты шаңнаан» - «Удостоили званием женщины», Самба-люндупа «Делегейниң чогум ээлери - арат чон» - «Настоящие хозяева мира - простой народ».

В этих стихотворениях доминируют сообщения-повествования о новом и старом мире, о достижениях Страны Советов и Советской Тувы. Обязательной составляющей этих текстов является опора на готовые риторические украшательства о новой жизни: «(Ленинниң) Алдын чүрээ» - «Золотое ленинское сердце», «Улус хөйнүң чырык хүнү, // Изиг чүрээвис Сталинга» - «Светлое солнце народное, // Наше пламенное сердце Сталин» Хойлакаа, «Октябрь революзу үнгенинден // Оттуг чаңнык дүшкенинден»«Словно Молния осветила землю // Когда вспыхнула Октябрьская революция» М. Идам-сюрюна и т. д.

Эти стихи непременно заканчиваются лозунговыми призывами:

\begin{tabular}{l|l}
$\begin{array}{l}\text { Революстуг изиг байыр! } \\
\begin{array}{l}\text { Ленинизм делгерезин! } \\
\text { (Хойлакаa) }\end{array}\end{array}$ & $\begin{array}{l}\text { Пламенный революционный привет! } \\
\text { Да здравствует ленинизм! }\end{array}$ \\
$\begin{array}{ll}\text { Чайынныг херел чаптылзын! } \\
\text { Чаа чурт делгерезин! }\end{array}$ & $\begin{array}{l}\text { Пусть сверкающий луч осветит всю землю! } \\
\text { Да здравствует новая страна! }\end{array}$ \\
& (С. Байыр)
\end{tabular}

Такие тексты в силу своей слабой художественной содержательности быстро выходят из круга читательского интереса, забываются и остаются лишь письменными свидетельствами ушедшей эпохи. Тем не менее, поэтические средства, задействованные в них, в дальнейшем творчески переосмысливаются художниками слова и входят в арсенал других авторов. Таким наглядным для нынешних читателей становится путь становления изобразительных средств публицистического стиха, поэтики восхваления и повествования, гражданской лирики советского периода.

В разделе «Стихотворения» сборника 1939 г. литературные произведения других авторов демонстрируют момент рождения поэтики художественной модальности в тувинской литературе. Образцом стихотворного произведения в начальный период становления новой поэтики тувинской литературы, бесспорно, считается стихотворение Пюрбю «Ленин».

Авторская индивидуальность, раскованность, эмоциональная насыщенность проявились в таких поэтических средствах как новая четкая ритмика, отход от канона народной песни и канона эпического повествования, выбор неканонической формы выражения, начальное и конечное грамматическое созвучия стихотворных строк, метафоризация, неосинкретизм кумуляции. Образ содержателен и независим от понятийного, идейного начала. Конкретный художественный образ Ленина захватывает чувства и разум читателя, являясь выражением внутреннего состояния автора и отражением внешнего мира - выражением общего пафоса эпохи. Модальность, изменчивость поэтики, колеблющаяся между риторическим словом традиционалистской поэтики и т. н. «простым словом», прозаизмом новой поэтики, в поэтике этих лет часто это может быть и газетная лексика агитационной литературы, что нисколько не ослабляет эмоционального накала авторского слова, его активной индивидуальности.

\section{Риторическое слово:}

$$
\begin{array}{r}
\text { Чырык хүннүң } \\
\text { херели дег }
\end{array}
$$

Чыргалалаңның
[Ленинские дела] словно лучи ясного солнца касаются

Родины райского существования [на земле] - СССР... 


\section{Прозаизм:}

Дириг кижиниң ханын сускун кылган, Дириг кижиниң эъдин чемиш кылган..
Кровью живого человека жажду свою утоляют, Мясом живого человека голод свой утоляют..

В стихотворении «Майның бири» («Первомай») начинающего поэта Степана Сарыг-оола ${ }^{1}$ ощущается изменение внешнего ракурса на события окружающего мира на внутренний пласт сознания, что также является свидетельством актуализации категории Автор:

\author{
Эртен эрте туруп келгеш, \\ Эргий көруп кээриңге, \\ Карак четпес төрээн чуртту \\ Каш өңнүг чечек бүргээн \\ Майның бири таан чараш! \\ Майның бири таан чырык! \\ Даңзгаар эртен туруп келгеш, \\ Tanтап дыңнап кээриңге, \\ Хөглұг ырның аянынга \\ Хөрек сагыш өөрүп келир...
}

\section{Ранним утром встаешь, Оглядишься вокруг,}

Безоглядные дали родной стороны Наполняются разноцветьем чудесным (...)

Как прекрасен Первомай!

Как светел Первомай!

На заре поднимаешься,

Прислушаешься к окружающим звукам,

Мелодии радостной песни

Душу и сердце веселят

Активные проявления категории Автор в поэтике новых стихотворных произведений вышеприведенных авторов свидетельствуют об интенсивности внедрения поэтики художественной модальности уже на начальном этапе истории тувинской литературы. Вместе с тем риторическое слово эстетики соцреализма присутствует непременно:

Айдың чырык оруувустуң

Аипас хүнү Сталинга...
Лунным светом озаренного нашего пути Вечное солнце Сталин...

Здесь же лозунговые призывы вполне гармонично завершают произведение:

\section{Маадырлыг өөрувұске \\ Майның бирниң байыр сөзу!}

Майның бирниң кызыл тугу

Делегейни хөме шывар!

Майның бирниң күштүг холу

Демир бекти үзе шавар!

Ажыг хинчек сөнээттинер! Амыр чыргал мөңгежирээр!
Нашим друзьям-героям

Торжественный клич Первомая!

Красное знамя Первомая

Накроет целиком весь мир!

Могучие руки Первомая

Разорвут железные оковы!

Горькая доля страданий исчезнет [навсегда]!

Вечное счастье-блаженство воцарится [во все времена]!

Жанр в поэтике художественной модальности уступает свои позиции категории Автор. Тем не менее, здесь мы наблюдаем рождение нового жанра шүлүк - «стихотворение», и эта жанровая форма, как пишет Д. С. Куулар, уже показывает свои разновидности (поэзия для детей, стихи-отклики, сатирические стихи) (Куулар, 1970: 35-37). Модальность в жанровом отношении отмечается в стихотворениях, содержащих в одном произведении строфы различных жанров: стихотворения, фольклорных форм благопожеланий, сказаний, пословиц, народной песни.

\footnotetext{
${ }^{1}$ В книге его имя указано как «Т. А. Сарыг-оол» - «Тюлюш Агбаан оглу Сарыг-оол».
} 
Например, произведение Тамбы-сюрюна «Көвей чоннуң хүндүлели // Күрүнениң Сүлде демдээ»«Награда народных масс // Государственный Герб» начинается:

1) с повествовательных интонаций эпического плана;

2) продолжается строфами в форме народных загадок;

3) завершается двустрочными строфами восхвалений-благопожеланий.

Например:

\section{1) Октябрьның оттуг чалбыыжы Орайындан чырыткан,}

Ай, хүннүң херели дег Ада чурт ССРЭ-ниң

Бады быжыг күжү-биле Бар бооп тывылган...
Пламенным огнем Октября Сверху осветивший,

Словно лучи луны и солнца Отечества СССР

Надежной могучей силою Рожденный [Герб]...
2) Алдын сарыг сөдургелиг,

Алдын сарыг уруктуг,

Ногаан торгу тоннуг,

Ногаан сарыг курлуг,

Кызыл былгаар идиктиг,

Кызыл торгу туктуг,

Эът боду хүлер болган,

Эки атты ээлеп алган -

Көвей чоннуң хүндүлели

Күрүнениң Сүлде демдээ.
С желто-золотистым арканом,

С желто-золотистым уруком ${ }^{1}$

В зеленом шелковом тоне ${ }^{2}$,

Подпоясанный желтым шелковым поясом,

В красных юфтевых сапогах,

С красным шелковым флагом

Телом сам из меди,

Снискавший доброе имя -

Гордость народных масс

Государственный Герб.
3) Хүрешкештиң шүглүп үнген

Күрүнениң оглу болган,

Депшилгелиг маңнап орар

Демиселдиң күжү болган

Калбак чоннуң эди болган

Каң бистиг кадыыр туткан

Беш диптиң түңүн түңнээн

Беш адыр сылдыс болган -

Көвей чоннуң хүндүлели

Күрүнениң Сүлде демдээ.
В схватке борцовской вышел победителем, Провозглашен сыном государства [нашего],

Распространившейся быстро,

Борьбы силой [могучею] стал,

Народных масс вещью-имуществом стал, Держащий в руках серп со стальным лезвием,

Одержавший победу на пяти континентах, Оказавшийся пятиугольной звездой -

Гордость народных масс Государственный Герб

Так, на примере текстов одного сборника мы проследили смену от традиционалистской эпохи до новой, индивидуально-творческой. Авторские песни, заключенные в канон народной песни; несамостоятельность Жанра как категории литературного творчества; активность категорий Автор и Стиль, новый неканонический жанр шүлүк, новая ритмика, новая образность, метафоризация; модальность поэтики и изменение внешнего ракурса на события окружающего мира на внутренний пласт

${ }^{1}$ Урук - шест для поимки лошадей с арканом.

${ }^{2}$ Тон - национальный одежда, халат. 
сознания - все эти эстетические преобразования являются свидетельствами актуализации поэтики художественной модальности в тувинской литературе.

\section{Заключение}

Тувинской литературой, начавшей свою историю в начале XX века, пройдены ранее в недрах словесности и народного творчества эпохи архаической и традиционалистской поэтики. Фольклоризм, как важнейший из эстетических принципов национальных литератур Сибири, показывает, что традиционалистская поэтика еще полностью не изжита современной тувинской национальной литературой. Таким образом, анализ поэтики художественных произведений 1930-х гг. показывает, что в тувинской литературе этого времени возможно выделение поэтических категорий, относящихся к разным литературным эпохам. Процесс зарождения тувинской национальной литературы в 1920-1930-е гг. связан с переходом тувинской словесности к новой стадии в истории поэтики. На примере произведений книги «Сььndь cogaaldar» («Избранные произведения») 1937 и 1939 гг., изданных в годы ТНР, видно, что новая поэтика в тувинской литературе 1930-х гг. вступает в свои права.

В то же время следует констатировать, что тувинская литература еще не вышла из лона традиционалистской поэтики. Жанровая размытость, явившаяся следствием активности канонических форм народной песни, риторичность, слитность идеи-образа (эйдос) - эти и другие характеристики отражают процесс становления поэтики художественной модальности. Эстетика новой поэтики сопряжена с художественными изменениями, способствующими становлению литературного сознания. Активизация категории Автор (повышенная активность авторского плана; переориентация с внешних, публичных пластов художественного сознания на самоличную, индивидуальную точку зрения); изменения в Стиле художественных произведений (эмоциональность конкретно-чувственного образа, новая ритмика, метафоризация); трансформация категории Жанр (неканонические жанры, рождение новых жанровых форм, жанровая модальность) - все отмеченные изменения системы художественновыразительных средств тувинской литературы являются приметами поэтики художественной модальности, что свидетельствует о коренных исторических изменениях в культуре Тувы.

\section{СПИСОК ЛИТЕРАТУРЫ}

Аверинцев, С. С., Андреев, М. Л., Гаспаров, М. Л., Гринцер, П. А., Михайлов, А. В. (1994) Категории поэтики в смене литературных эпох // Историческая поэтика. Литературные эпохи и типы художественного сознания / отв. ред. П. А. Гринцер. М. : Наследие. 512 с. С. 3-38.

Бахтин, М. М. (1986) Литературно-критические статьи. М. : Художественная литература. 543 с.

Бройтман, С. Н. (2004) Теория литературы : учеб. пособие для студ. филол. фак. высш. учеб. заведений : в 2 т. / под ред. Н. Д. Тамарченко. М. : Издательский центр «Академия». Т. 2. Историческая поэтика. 368 с.

Добренко, Е. А. (2007) Социалистический реализм и реальный социализм (советская эстетика и критика и производство реальности) [Электронный ресурс] // Colloquia. P. 57-92. URL: http://www.llti.lt/failai/Nr18_04_ Dobrenko.pdf (дата обращения: 22.06.2020).

Донгак, У. А. (2010) Отражение особенностей переходного периода от фольклора к литературе в творчестве С. Сарыг-оола // О творческом наследии С. А. Сарыг-оола. Материалы научно-практической конференции, посвященной 100-летию народного писателя Тувы С. А. Сарыг-оола / отв. ред. К.А. Бичелдей. Кызыл : ОАО «Тываполиграф». 232 с. С. 54-58.

Донгак, У. А. (2012а) Коллективное авторство как одно из проявлений переходного периода от фольклора к литературе // Вестник Бурятского государственного университета. Вып. 10. С. 152-155.

Донгак, У. А. (2012b) Особенности переходного периода от фольклора к литературе: от мифопоэтики к индивидуальному авторскому творчеству // Научное обозрение Саяно-Алтая. № 2(4). С. 70-74.

Донгак, У. А. (2012c) Первые оригинальные сочинения тувинской литературы 1920-1930-х годов на старомонгольском письменном языке // Монгол хэл, соёлын тулгамдсан асуудлууд. II салбар. Улаанбаaтар : IAMS Secretariat. С. 310-312.

Донгак, У. А. (2013) Особенности литературного творчества 1920-х - начала 1940-х годов в Туве: [глава I] // История тувинской литературы (2013) / отв. ред. К. А. Бичелдей. Новосибирск : Изд-во СО РАН. Т. І. Истоки. Литература Тувинской Народной Республики (1921-1944). 266 с. С. 109-126.

История русской литературы XX века (20-90-е годы). Основные имена (1998) / под ред. С. И. Кормилова. М. : МГУ им. М.В. Ломоносова. 480 с. 
История тувинской литературы (2013) / отв. ред. К. А. Бичелдей. Новосибирск : Изд-во СО РАН. Т. І. Истоки. Литература Тувинской Народной Республики (1921-1944). 266 с.

Калзан, А. К. (1958) Тувинская драматургия периода THP // Ученые записки. Вып. IV. Кызыл : Тувинское книжное издательство. С. 120-136.

Калзан, А. К. (1961) О послереволюционном фольклоре // Ученые записки. Вып. IX. Кызыл : Тувинское книжное издательство. С. 253-259.

Кенин-Лопсан, М. Б. (1995) Барыкаан Донгак // Улуг-Хем. № 2. Ар. 94-101. (На тув. яз.)

Кременцов, Л. П. (2016) Русская литература в XX веке. Обретения и утраты: учебное пособие. 4-е изд., стер. М. : Флинта. 224 с.

Куулар, Д. С. (1970) Тувинская поэзия: очерк истории. Кызыл : Тувинское книжное издательство. 140 с.

Литовская, М. А. (2008) Социалистический реализм как «образцовый» творческий метод // Филологический класс. № 1 (19). С. 14-21.

Маадыр, М. С. (2011) Книжная культура Тувинской народной республики: позитивные и негативные тенденции [Электронный ресурс] // Новые исследования Тувы. № 2-3. URL: https://nit.tuva.asia/nit/article/view/406 (дата обращения: 12.05.2020).

Маадыр, М. С., Седип-оол, М. М. (2020) Газетный фонд Национального архива Республики Тыва // Новые исследования Тувы. № 2. С. 87-102. DOI: www.doi.org/10.25178/nit.2020.2.6

Мижит, Л. С. (2013) Формирование тувинской поэзии в период Тувинской Народной Республики // История тувинской литературы / отв. ред. К. А. Бичелдей. Новосибирск: Изд-во СО РАН. 266 с. Т. І. Истоки. Литература Тувинской Народной Республики (1921-1944). 266 с. С. 151-184.

Самдан, 3. Б. (1987) От фольклора к литературе: на материале тувинской прозы 40-70-х годов. Кызыл: Тувинское книжное издательство. 80 с.

Тамарченко Н. Д., Тюпа В. И., Бройтман С. Н. (2004) Теория литературы : учеб. пособие для студ. филол. фак. высш. учеб. заведений: в 2 т. / под ред. Н. Д. Тамарченко. М. : Издательский центр «Академия». Т. 1. Теория художественного дискурса. Теоретическая поэтика. 512 с.

Танова, Е. Т. (1979) Периодическая печать Тувы (1921-1944 гг.). Кызыл : Тувинское книжное издательство. 112 с.

Тыва литератураның төөгүзүнүң очерктери [Очерки истории тувинской советской литературы] (1975) / Калзан А. К., Куулар Д. С., Хадаханэ М. А. Кызыл : Тываның ном үндүрер чери. 331 ар. (На тув. яз.)

Чудакова, М. О. (2002) «Военное» стихотворение Симонова «Жди меня...» (июль 1941 г.) в литературном процессе советского времени [Электронный ресурс] // Новое литературное обозрение (HЛO), № 6. URL: https:// magazines.gorky.media/nlo/2002/6/voennoe-stihotvorenie-simonova-zhdi-menya-iyul-1941-g-v-literaturnomproczesse-sovetskogo-vremeni.html (дата обращения: 01.05.2020).

Дата поступления: 01.06.2020 г.

\section{REFERENCES}

Averintsev, S. S., Andreev, M. L., Gasparov, M. L., Grintser, P. A. and Mikhailov, A. V. (1994) Kategorii poetiki v smene literaturnykh epokh [Categories of poetics in the change of literary eras]. In: Istoricheskaia poetika. Literaturnye epokhi $i$ tipy khudozhestvennogo soznaniia [Historical poetics. Literary eras and types of artistic consciousness] / ed. by P. A. Grintser. Moscow, Nasledie. 512 p. Pp. 3-38. (In Russ.) (In Russ.).

Bakhtin, M. M. (1986) Literaturno-kriticheskie stat'i [Literary and critical articles]. Moscow, Khudozhestvennaia literatura. 543 p. (In Russ.).

Broitman, S. N. (2004) Teoriia literatury [Theory of literature] : textbook for students: in 2 vols. / ed. by N. D. Tamarchenko. Moscow, Izdatel'skii tsentr “Akademiia”. Vol. 2. Istoricheskaia poetika. 368 p. (In Russ.).

Dobrenko, E. A. (2007) Sotsialisticheskii realizm i real'nyi sotsializm (sovetskaia estetika i kritika i proizvodstvo real'nosti) [Socialist realism and real socialism (Soviet aesthetics and criticism and the production of reality)]. Colloquia, pp. 57-92 [online] Available at: http://www.llti.lt/failai/Nr18_04_Dobrenko.pdf (access date: 22.06.2020). (In Russ.).

Dongak, U. A. (2010) Otrazhenie osobennostei perekhodnogo perioda ot fol'klora k literature v tvorchestve S. Sarygoola [Reflections of the features of the transitional period from folklore to literature in the works of S. Saryg-ool]. In: O tvorcheskom nasledii S. A. Saryg-oola [On the creative heritage of S. A. Saryg-ool]. Proceedings of the conference dedicated to the 100th anniversary of the people's writer of Tuva S. A. Saryg-ool / ed. by K. A. Bicheldei. Kyzyl, OAO «Tyvapoligraf». 232 p. Pp. 54-58. (In Russ.). 
Dongak, U. A. (2012a) Kollektivnoe avtorstvo kak odno iz proiavlenii perekhodnogo perioda ot fol'klora k literature [Collective authorship as one of the manifestations of the transition period from folklore to literature]. Vestnik Buriatskogo gosudarstvennogo universiteta, vol. 10, pp. 152-155. (In Russ.).

Dongak, U. A. (2012b) Osobennosti perekhodnogo perioda ot fol'klora k literature: ot mifopoetiki k individual'nomu avtorskomu tvorchestvu [Features of the transition period from folklore to literature: from mythopoetics to individual author's creativity]. Nauchnoe obozrenie Saiano-Altaia, no. 2(4), pp. 70-74. (In Russ.).

Dongak, U. A. (2012c) Pervye original'nye sochineniia tuvinskoi literatury 1920-1930-kh godov na staromongol'skom pis'mennom iazyke [The earliest original works of Tuvan literature in Old Mongol language, 1920-1930s]. Mongol khel, soelyn tulgamdsan asuudluud. II salbar. Ulaanbaatar, IAMS Secretariat. Pp. 310-312. (In Russ.).

Dongak, U. A. (2013) Osobennosti literaturnogo tvorchestva 1920-kh - nachala 1940-kh godov v Tuve: glava I [Features of literary creativity of the 1920s - early 1940s in Tuva: [Chapter I]]. In: Istoriia tuvinskoi literatury [A History of Tuvan Literature] (2013). Ed. by K. A. Bicheldey. Novosibirsk, Nauka. Vol. 1. 264 p. Pp. 109-126. (In Russ.).

Istoriia russkoi literatury XX veka (20-90-e gody). Osnovnye imena [History of Russian literature of the XX century (1920s-1990-s). Principal name] (1998) / ed. by S. I. Kormilov. Moscow, MGU im. M. V. Lomonosova. 480 p. (In Russ.).

Istoriia tuvinskoi literatury [A History of Tuvan Literature] (2013). Ed. by K. A. Bicheldey. Novosibirsk, Nauka. Vol. 1. 264 p. (In Russ.).

Kalzan, A. K. (1958) Tuvinskaia dramaturgiia perioda TNR: o p'esakh S. K. Toka «Tönggür-ool», «Zhenshchina», «UzunKara i Semis-Kara» [Tuvan dramaturgy of the TPR period: On S.K. Toka's plays “Tengur-ool”, “Woman”, "Uzun-Kara and Semis-Kara”]. Uchenye zapiski TNIIIaLI. Kyzyl, s. n. Vol. 6. Pp.115-136. (In Russ.).

Kalzan, A. K. (1961) O poslerevoliutsionnom fol'klore [On post-revolutionary folklore]. Uchenye zapiski. Vol. IX. Kyzyl, Tuvan book publisher. Pp. 253-259. (In Russ.).

Krementsov, L. P. (2016) Russkaia literatura v XX veke. Obreteniia i utraty [Russian literature in the twentieth century. Gains and losses] : textbook. $4^{\text {nd }}$ ed. Moscow, Flinta. 224 p. (In Russ.).

Kuular, D. S. (1970) Tuvinskaia poeziia: ocherk istorii [Tuvan poetry: an essay on its history]. Kyzyl, Tuvan book publisher. 140 p. (In Russ.).

Litovskaia, M. A. (2008) Sotsialisticheskii realizm kak «obraztsovyi» tvorcheskii metod [Socialist realism as an “exemplary” creative method]. Filologicheskii klass, no. 1 (19), pp. 14-21. (In Russ.).

Maadyr, M. S. (2011) Knizhnaia kul'tura Tuvinskoi narodnoi respubliki: pozitivnye i negativnye tendentsii [Book culture of the Peoples' Republic of Tuva: positive and negative tendencies]. New Research of Tuva, n. 2-3 [online] Available at: https://nit.tuva.asia/nit/article/view/406 (access date: 12.05.2020).

Maadyr, M. S. and Sedip-ool, M. M. (2020) Gazetnyi fond Natsional'nogo arkhiva Respubliki Tyva [Newspaper collections at the National Archives of the Republic of Tuva]. New Research of Tuva, no. 2, pp. 87-102. (In Russ.). DOI: www.doi. org/10.25178/nit.2020.2.6

Mizhit, L. S. (2013) Formirovanie tuvinskoi poezii v period Tuvinskoi Narodnoi respubliki [The rise of Tuvan poetry under the Tuvan People's Republic]. In: Istoriia tuvinskoi literatury [A History of Tuvan Literature] (2013). Ed. by K. A. Bicheldey. Novosibirsk, Nauka. Vol. 1. 264 p. Pp. 151-184. (In Russ.).

Samdan, Z. B. (1987) Ot fol'klora k literature: na materiale tuvinskoi prozy 40-70-kh godov [From folklore to literature: the case of Tuvan prose of the 1940s-1970s]. Kyzyl, Tuvan book publisher. 80 p. (In Russ.).

Tamarchenko N. D., Tiupa V. I. and Broitman S. N. (2004) Teoriia literatury [Theory of literature]: textbook in 2 vols. / ed. by N. D. Tamarchenko. Moscow, Izdatel'skii tsentr «Akademiia». Vol. 1. Teoriia khudozhestvennogo diskursa. Teoreticheskaia poetika [Theory of literary discourse. Theoretical poetics]. 512 p. (In Russ.).

Tanova E. T. (1979) Periodicheskaia pechat' Tuvy (1921-1944 gg.) [Periodical press in Tuva, 1921-1944]. Kyzyl, Tuvan book publ. 112 p. (In Russ.).

Chudakova, M. O. (2002) «Voennoe» stikhotvorenie Simonova «Zhdi menia...» (iiul' 1941 g.) v literaturnom protsesse sovetskogo vremeni [Simonov's wartime poem Wait for me..." (July 1941) in the literary process of the Soviet time]. Novoe literaturnoe obozrenie (NLO), no. 6 [online] Available at: https://magazines.gorky.media/nlo/2002/6/voennoestihotvorenie-simonova-zhdi-menya-iyul-1941-g-v-literaturnom-proczesse-sovetskogo-vremeni.html (access date: 01.05.2020). (In Russ.).

Kenin-Lopsan, M. B. (1995) Barykaan Dongak. Ulug-Khem, no. 2, pp. 94-101. (In Tuv.)

Tyva literaturanyng töögüzününg ocherkteri [Essays on the history of Tuvan Soviet literature] (1975) / Kalzan A. K., Kuular D. S. and Khadakhane M. A. Kyzyl, Tuvan book publisher. 331 p. (In Tuv.) 